\title{
Diel activity of Sarpa salpa (Sparidae) by ultrasonic telemetry in a Posidonia oceanica meadow of Corsica (Mediterranean Sea)
}

\author{
Catherine Jadot $^{\mathrm{a}, *}$, Michaël Ovidio ${ }^{\mathrm{b}}$, Jacques Voss ${ }^{\mathrm{a}}$ \\ a'University of Liege, Department of Eco-ethology, Aquarium “M. Dubuisson”, Quai Van Beneden 22, 4020, Liege, Belgium \\ ${ }^{\mathrm{b}}$ University of Liege, Laboratory of Fish Demography and Hydroecology, Chemin de la Justice 10, 4500, Tihange, Belgium
}

Received 21 May 2002; accepted 7 October 2002

\begin{abstract}
In the Mediterranean Sea, the fish Sarpa salpa (Sparidae) is the only vertebrate grazer of Posidonia oceanica meadows. In order to gain knowledge about the behaviour of $S$. salpa and a better understanding of the meadow's primary production recycling, an original study was designed using ultrasonic telemetry to investigate activity patterns and space utilisation in the field. During June-September 2000, we compared diel movements of six adult S. salpa (249-317 mm FL and 313-633 g) in the Bay of Calvi. These fish were tagged by intraperitoneal insertion of ultrasonic transmitters. Their positions were recorded with a directional hydrophone from a small boat with an accuracy between 10 and $50 \mathrm{~m}$, depending on the local environment. The tracking duration ranged from 3 to 22 days (average $11.8 \pm 7.3$ ). Locations were performed from at least dawn to dusk or early night, and one fish was tracked during the entire 24-h cycle. Fish were more mobile during the twilight periods, but statistical analysis indicated individual differences for the precise period of mobility. Two major behavioural patterns were observed: first, the fish remained in close vicinity of the harbour during the day and moved away to the north or the south at dusk to access nocturnal sites, occupying a home range of about 4.3 ha. The second behavioural pattern involved persistent occupation of the same sites during day and night within a relatively restricted home range (about 0.8 ha). Great variation in mobility was found and the same individual fish could show both kinds of behaviour. (C) 2002 Ifremer/CNRS/Inra/IRD/Cemagref/Éditions scientifiques et médicales Elsevier SAS. All rights reserved.
\end{abstract}

\section{Résumé}

Rythmes d'activité de Sarpa salpa (Sparidés) dans un herbier de Posidonia oceanica : étude par télémétrie acoustique en mer Méditerranée, Corse. En Méditerranée, la saupe ( $S$. salpa) est le seul poisson brouteur de l'herbier à $P$. oceanica. Améliorer nos connaissances sur le comportement de $S$. salpa permet une meilleure compréhension du recyclage de la production primaire de l'herbier. De juin à septembre 2000, 6 saupes (249-317 mm FL et 313-633 g) capturées dans la baie de Calvi, proche du port de Stareso ont été équipées d'un émetteur à ultrason par une insertion péritonéale et leurs positions ont été enregistrées avec un hydrophone directionnel à bord d'un bateau, avec une précision de 10 à $50 \mathrm{~m}$, en fonction de l'environnement local. Les poissons ont été suivis de 3 à $22 \mathrm{j}$ (moyenne $11,8 \pm 7,3 \mathrm{j}$ ) et ont été localisés en continu depuis l'aube jusqu'au crépuscule ou au début de la nuit. Un individu a été localisé sur un cycle complet de $24 \mathrm{~h}$. Les individus suivis semblent en général plus mobiles durant l'aube et le crépuscule, même si des différences individuelles ont été observées. Deux principaux types de comportements ont été constatés : (1) la saupe reste à proximité du port durant le jour et se déplace ensuite au crépuscule vers le Nord ou le Sud et occupe des espaces vitaux qui peuvent s'étendre jusqu'à 4,3 ha, (2) le comportement correspond à une occupation permanente du même site pendant le jour et la nuit avec un espace vital, home range, relativement restreint (0,8 ha). D'un jour à l'autre, un poisson peut présenter les deux types de comportement. (C) 2002 Ifremer/CNRS/Inra/IRD/Cemagref/Éditions scientifiques et médicales Elsevier SAS. Tous droits réservés.

Keywords: Ultrasonic tracking; Grazer; Sparidae; Posidonia; Mediterranean Sea

\footnotetext{
* Corresponding author.

E-mail address: Catherine.Jadot@ulg.ac.be (C. Jadot).
} 


\section{Introduction}

Posidonia oceanica is the dominant seagrass species in Mediterranean coastal waters, where it contributes significantly to coastal primary productivity (Ros et al., 1984; Pergent et al., 1994). It exerts important roles as spawning and nursery areas, sediment fixer and oxygen producer (Bay, 1984; Mazzella et al., 1992). The role of macroconsumers, however, in the regulation and transformation of its production has been poorly investigated (Mazzella et al., 1992; Cebrian et al., 1996; Havelange et al., 1997; Lepoint et al., 2000). Among the three potential consumers, the sparid Sarpa salpa (L.) (Velimirov, 1984; Verlaque 1990; Jadot et al., 2000a, b), the isopod Idotea baltica Pall. and the echinid Paracentrotus lividus Lam. (Ott and Maurer, 1977; Dance, 1987), S. salpa can contribute to up to $75 \%$ of the total herbivore consumption of $P$. oceanica (Cebrian et al., 1996).

Herbivorous pressure can vary greatly among meadows, as shown by Alcoverro et al. (1997) and throughout the different periods of the year (Peirano, 2001). Abundant literature has suggested that the ecological impact of herbivorous fishes in temperate seas could be greater than is generally thought, especially in the sheltered shallow $P$. oceanica meadow, where herbivores represent a significant part of the fish fauna (40-70\% in biomass), which gives them a considerable ecological weight (Harmelin-Vivien, 1983; Francour, 1997, 2000; Ruitton, 2000). Sarpa salpa lives in schools along the rock-bottomed coast. It is found in depths of 0-40 m (Verlaque, 1990; Mendez-Villamil, 2001). Its density has been estimated from 0.03 to 77.6 ind $10 \mathrm{~m}^{-2}$ (Francour, 1997; Harmelin-Vivien and Francour, 1997). Sarpa salpa feed on the P. oceanica meadows around Calvi in a destructive manner, ingesting large quantities of photosynthesising leaf (Velimirov, 1984; Havelange, 1997) and plays a preponderant role in the differentiation of alga communities in Mediterranean (Verlaque, 1990). Therefore, a global comprehension of this fish's behaviour is essential for management of resources and design of protected areas, either locally or more generally in the Mediterranean.

In order to determine the space and food resources utilisation, the daily activity rhythms and the habitat preference of the $S$. salpa, we conducted an acoustic telemetry study and monitored the movement of six tagged fish at the meadow of the Bay of Calvi.

\section{Material and methods}

The study was carried out near the Oceanographic and Underwater Scientific Field Station STARESO ("Station de Recherche océanographique et sous-marine") (Calvi, Corsica, $42^{\circ} 35^{\prime} \mathrm{N}-8^{\circ} 43^{\prime} \mathrm{E}$ ) (Fig. 1) between June and September 2000. The coast near the station is formed by granite rocks going down into the sea to a depth of $8 \mathrm{~m}$ (in front of the station) to $30 \mathrm{~m}$ (at the end of Revellatta cape). These rocks

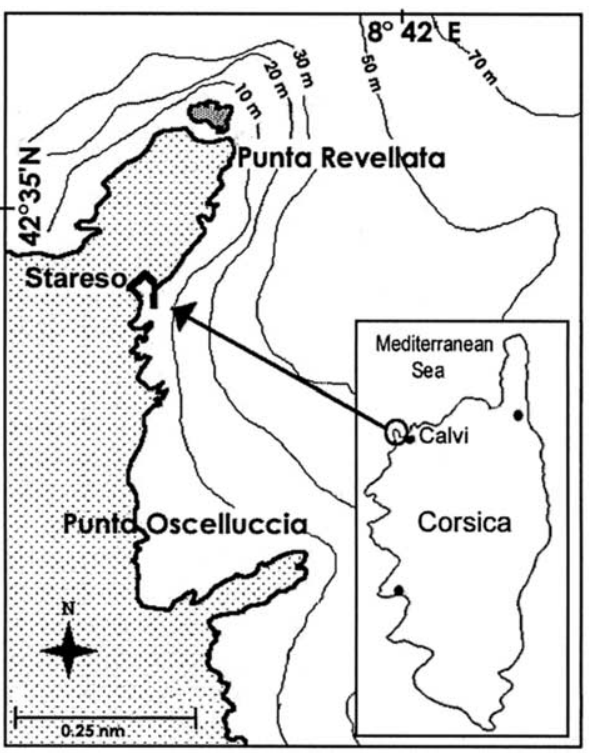

Fig. 1. Study site, near STARESO (Oceanographic and Underwater Research Field Station) Revellata Cape, located at Calvi, Corsica, where the fish were caught and released.

are covered by macroalgal vegetation dominated by Cystoseira. Over the rocky area, the $P$. oceanica grows on a gently sloped bottom down to the $38 \mathrm{~m}$ isobath where the meadow is replaced by a sandy-gravel bottom.

\subsection{Capture and tagging technique}

A preliminary study has shown that internal implantation was more suitable than external fixation for this species (Jadot, unpublished data). The six S. salpa used in this study were captured with gill nets during SCUBA diving near Stareso in shallow waters $(<15 \mathrm{~m})$. After capture, the fish were directly transferred into tanks containing water from the capture site, in order to minimise perturbations.

Before tagging, the fish were anaesthetised using a $0.2 \mathrm{ml} \mathrm{l}^{-1}$ solution of 2-phenoxy-ethanol. When the fish were fully anaesthetised, showing no reaction to external stimuli, they were placed ventral side up into a V-shaped support adjusted to their morphology. The whole body except the ventral side stayed in the water to avoid dehydration and to permit a continuous oxygenation of the gills. After cleaning in iso-Betadine, the transmitters VEMCO Ltd. V8-1L $\left(38 \times 8 \mathrm{~mm}^{2}\right)$ and V8-2L $\left(24 \times 8 \mathrm{~mm}^{2}\right)$ were inserted into the peritoneal cavity of the fish through a $25 \mathrm{~mm}$ incision on the mid ventral-line, $25 \mathrm{~mm}$ anterior to the anus. The incision was closed by two separate stitches using sterile non-resorbable thread. The acoustic positioning transmitters did not exceed $1.1 \%$ of the body weight of the fish (Table 1). The procedure took less than $10 \mathrm{~min}$. For recovery, fish were placed in a fresh seawater tank. As soon as they had recovered spontaneous swimming, they were released in Stareso's harbour (capture site) in order to avoid trauma due to long postoperative care. 
Table 1

Characteristics of the tagged fish in 2000

\begin{tabular}{|c|c|c|c|c|c|c|c|c|c|c|}
\hline $\begin{array}{l}\text { Fish } \\
\text { code }\end{array}$ & $\begin{array}{l}\text { Fork length } \\
(\mathrm{mm})\end{array}$ & Weight (g) & TW (g) & TBWR (\%) & $\begin{array}{l}\text { Date and hour } \\
\text { of release }\end{array}$ & $\begin{array}{l}\text { Time } \\
\text { tracked } \\
\text { (days) }\end{array}$ & $\begin{array}{l}\text { Battery } \\
\text { expected life } \\
\text { (days) }\end{array}$ & $\begin{array}{l}\text { Reason of } \\
\text { tracking's } \\
\text { end }\end{array}$ & $\begin{array}{l}\text { Transmitter } \\
\text { frequency } \\
(\mathrm{kHz})\end{array}$ & $\begin{array}{l}\text { Transmitter } \\
\text { pulse rate } \\
(\mathrm{ms})\end{array}$ \\
\hline 1 & 289 & 536 & 2.7 & 0.5 & 08 June $15: 15$ & 3 & 10 & $\mathrm{~L}$ & 65.5 & 1000 \\
\hline 2 & 288 & 490 & 3.5 & 0.7 & 13 June $16: 15$ & 5 & 21 & $\mathrm{D}$ & 76.8 & 1200 \\
\hline 3 & 283 & 376 & 3.5 & 0.9 & 21 June 10:00 & 12 & 13 & $\mathrm{~T}$ & 76.8 & 1200 \\
\hline 4 & 317 & 633 & 2.7 & 0.4 & 05 July 18:00 & 11 & 10 & $\mathrm{~T}$ & 76.8 & 1000 \\
\hline 5 & 249 & 313 & 3.5 & 1.1 & 02 Sept. $18: 45$ & 22 & 21 & $\mathrm{~T}$ & 65.5 & 1000 \\
\hline 6 & 284 & 447 & 3.5 & 0.7 & 02 Sept. $18: 45$ & 18 & 21 & $\mathrm{~L}$ & 69.0 & 1500 \\
\hline
\end{tabular}

TW, transmitter weight in air; TBWR, transmitter to body weight ratio in air; L, loss of the fish; D, death of the fish; T, end of the transmitter battery life.

\subsection{Manual tracking}

Fish were located approximately every $30 \mathrm{~min}$ using a VR60 (VEMCO Ltd) receiver and a V10 directional hydrophone. In accordance to Holland et al. (1992), locations were made from a small boat to allow tracking by a single operator and rapid changes of direction, and to reduce the hydrodynamic and mechanical noise.

Locations of the fish were performed as follows: (1) detection of the signal (maximum range: $500 \mathrm{~m}$ ), (2) rotation of the directional hydrophone through an arc, and determination of the signal direction, (3) movement in the direction of the signal till its maximum intensity, (4) location of the fish by biangulation, and (5) recording of the fish position taking bearings in three landmarks.

The accuracy estimation of 10-50 $\mathrm{m}$ was defined by the location of a manually placed transmitter in the same environment at different positions. Moreover, seagrass, rocks, and other obstacles can reduce the power of the signal, and therefore may alter the accuracy of the location.

Due to the size and characteristics of the boat, and for security reasons, it was impossible to track the fish in severe weather and sea conditions or during the night. Time and estimated position were recorded on a map. Fish were located over a period ranging from 3 to 22 days, at least from dawn through dusk and into the early night.

\subsection{Data treatment}

Mean distances travelled per half-hour were defined as the distance between two consecutive localisations. For each location, maximum depth was determined by overlapping a bathymetric map.

Water column was divided into four classes $(0-5 \mathrm{~m}$, 5-10 m, 10-20 m and >20 m). Contingency tables were used to test if $S$. salpa differently occupied these four depth classes by counting the number of locations of tracked fish in the four depth categories during the different periods of the 24 h-cycle (night, day, dawn and early night). Dawn and dusk period were defined as $2 \mathrm{~h}$ each (dawn 07:00-09:00, day 09:00-19:00, dusk 19:00-21:00, night 21:00-07:00).

The extent of movements travelled by each fish and by the six individuals together during the four periods of the 24-h cycle (night, dawn, day, dusk) was tested against each other by Scheffe F-tests at 0.05 level of significance.

The software Arcview and the extension Animal Movement (Hooge and Eichenlaub, 1997) were used to analyse space utilisation by individual $S$. salpa. This program calculated a fixed kernel home range utilisation distribution as a grid coverage using ad hoc calculation of a smoothing parameter $(H)$ by the least squares cross validation. The Kernel Home range is calculated for a probability of 95,75 , 50 and $25 \%$ to find the fish.

\section{Results}

\subsection{Diel activity pattern}

A total of 1755 positional fixes were monitored during this study between June 8 and September 23, 2000. The tracking efforts were conducted during four main periods of time: dawn, day, dusk and early night. The tagged individuals showed contrasting patterns of movement during these four periods of the 24-h cycle (Table 2 and Fig. 2). The six fish were less mobile during daylight. The distances between two successive localisations were quite short and only exceptionally exceeded 50 or even $100 \mathrm{~m}$. However, few data were collected during the night. Statistical analyses indicated the existence of inter-individuals differences in mobility with regards to particular periods of the day (Table 2). Fish $n^{\circ} 1$ moved essentially during the night. Fish $n^{\circ} 2$ displayed shorter movements during the day than during the other periods. Fish $\mathrm{n}^{\circ} 3,5$ and 6 essentially moved from the end of the day to the early night, and to a lesser degree during dawn. Fish $n^{\circ} 4$ displayed longer movements in the dawn period. When the data of the six fish were pooled together, it appeared that the maximum mobility, defined as the distance maximum travelled between two locations, occurred at dusk (mean $61 \pm 129 \mathrm{~m}$ ), then during dawn (mean $35.7 \pm 58.2 \mathrm{~m}$ ), night (mean $21.3 \pm 44.1 \mathrm{~m}$ ) and finally during day-time (mean $11.9 \pm 22.7 \mathrm{~m}$ ). Nevertheless, as the fish were rarely tracked during the entire night, comparisons related to this latter period must be interpreted with great caution. 
Table 2

Comparison of movements during the four periods of the 24-h cycle (=dawn 07:00-09:00, day 09:00-19:00, dusk 19:00-21:00, night 21:00-07:00)

\begin{tabular}{|c|c|c|c|c|c|c|c|}
\hline Fish Code & Dawn vs. day & Dawn vs. dusk & Dawn vs. night & Day vs. dusk & Day vs. night & Dusk vs. night & $\begin{array}{l}\text { Maximum } \\
\text { mobility }\end{array}$ \\
\hline 1 & 0.99 & - & 0.28 & 0.99 & $*$ & 0.12 & Night \\
\hline 2 & 0.09 & 0.92 & 0.29 & $* *$ & $* * *$ & 0.65 & Dusk \\
\hline 3 & 0.88 & 0.06 & 0.80 & $* * * *$ & 0.97 & $* *$ & Dusk \\
\hline 4 & $* *$ & 0.13 & $*$ & 0.86 & 0.86 & 0.63 & Dawn \\
\hline 5 & 0.09 & $* * *$ & 0.29 & $* * * *$ & 0.99 & $* * * *$ & Dusk \\
\hline 6 & $* *$ & 0.99 & $*$ & $* *$ & 0.96 & $*$ & Dawn/ dusk \\
\hline Total & $* * * *$ & $* * *$ & 0.14 & $* * * *$ & 0.26 & $* * * *$ & Dusk \\
\hline
\end{tabular}

Movement data for different periods were tested against each other by Scheffe's test at 0.05 level of significance. Total line gathers the data of the six fish.

$* P<0.05$

$* * P<0.01$

$* * * P<0.001$

$* * * * P<0.0001$

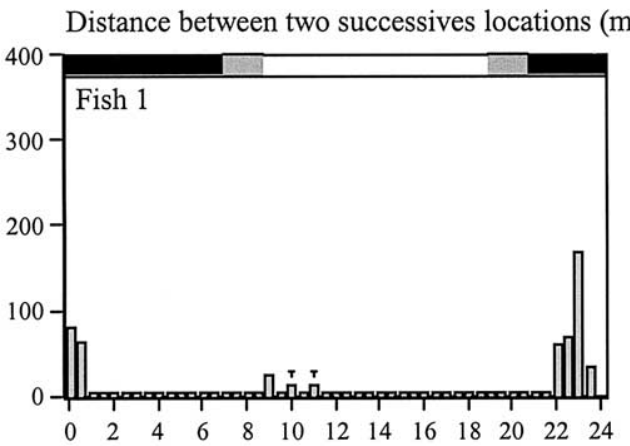

Distance between two successives locations (m)
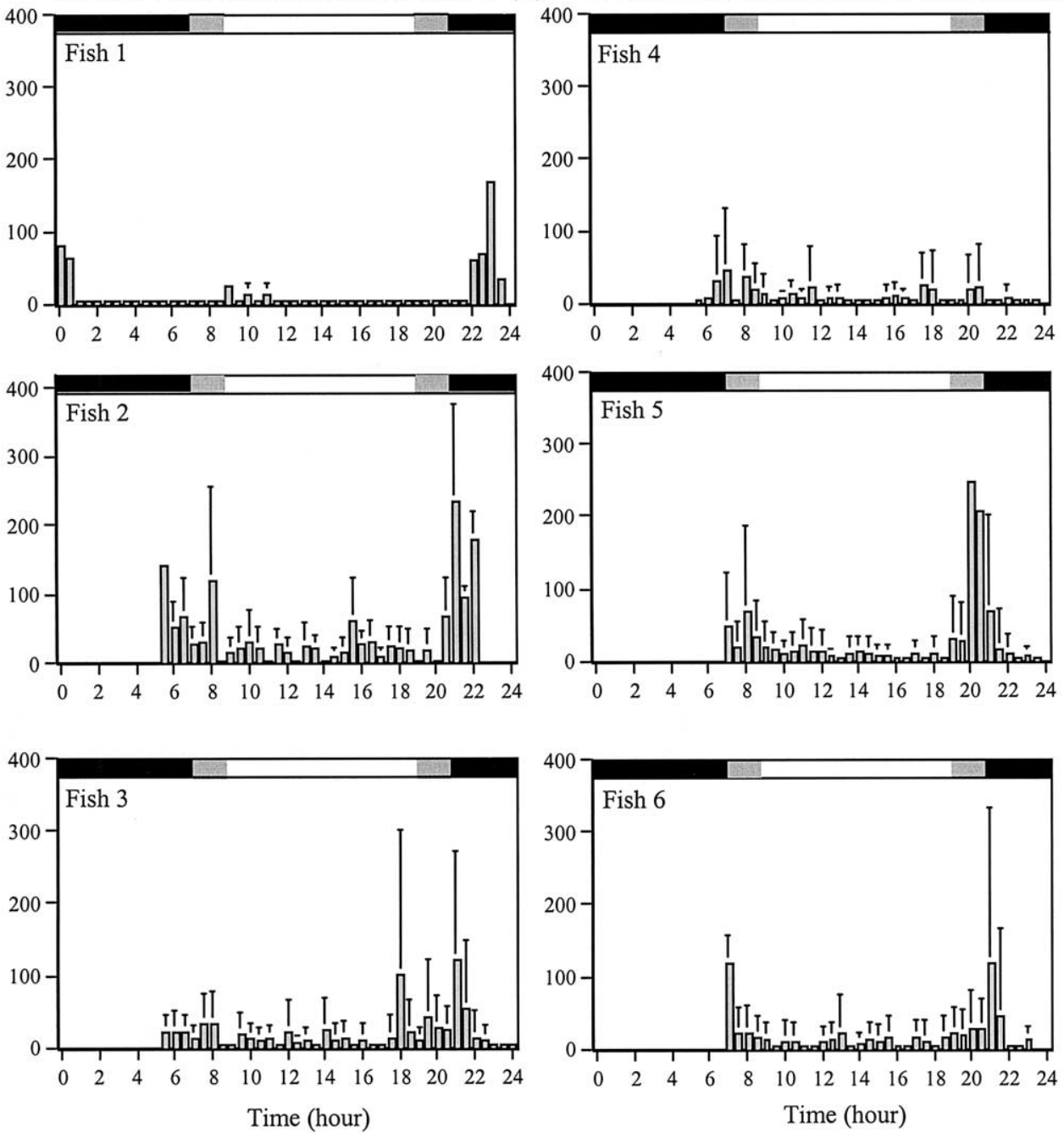

Fig. 2. Half-hourly means $( \pm S D)$ of distances travelled for each tracked individual between successive locations over the entire tracking period. In the upper part of each graph, twilight periods are represented in grey, the day in white and the night in black. Bars: standard deviation.

\subsection{Home range and movements}

Home range for the six tagged fish (Table 3) showed inter-individual differences in extension ranging from
0.85 ha to 4.30 ha, being spatially close to each other or even superimposed. Four home ranges out of the six tagged fish are shown on Fig. 3. 
Table 3

Home range in $\mathrm{m}^{2}$ of the six-tagged fish at a probability $95,75,50$ and $25 \%$ to find the fish

\begin{tabular}{lcrlr}
\hline \multirow{2}{*}{ Fish code } & \multicolumn{2}{l}{ Probability } & & \\
\cline { 2 - 5 } & $95 \%$ & $75 \%$ & $50 \%$ & $25 \%$ \\
\hline 1 & 8530 & 4990 & 2440 & 1580 \\
2 & 31770 & 15680 & 6100 & 3110 \\
3 & 27660 & 14410 & 6230 & 3970 \\
4 & 10230 & 5890 & 2560 & 1520 \\
5 & 42950 & 18690 & 3250 & 3250 \\
6 & 8660 & 5020 & 1470 & 560 \\
\hline
\end{tabular}

Two major kinds of behavioural pattern within the home range were observed. First an unchanged occupation of the harbour site, and secondly, a daily occupation of the harbour followed by a movement at dusk either to the Punta Revellata (North) or to the Punta Oscelluccia (South) (Fig. 1). Individual fish presented both the pattern of movement from one day to another, but also, a fish repeated the same behaviour during the whole tracking period. These major different patterns in behaviour are illustrated on Fig. 4. On the morning of June10th, fish A stayed at the harbour site and started a movement at 22:30 and reached the Punta Revellata after $2 \mathrm{~h}$, which represents an approximate speed of 0.24 Body Length at Fork (BLF per second) (Fig. 4). Fish E was continually located at $250 \mathrm{~m}$ south of the harbour's station from $6: 45$ to $19: 00$, began to move from 19:30 to 20:00 toward the Punta Oscelluccia and stayed there at least
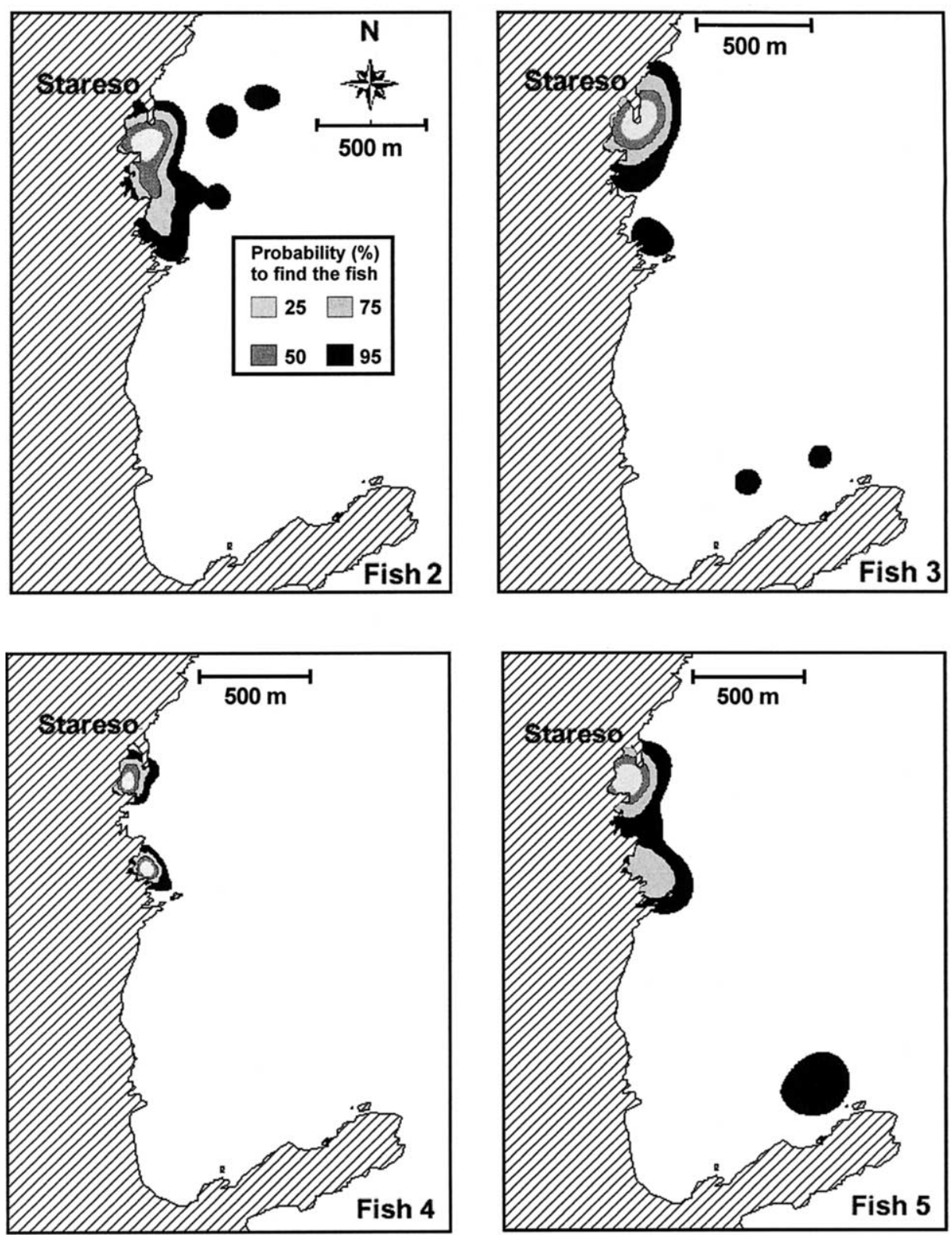

Fig. 3. Pattern in use of space within the home range for the six tracked Sarpa salpa over all tracking days at the Bay of Calvi, visualised by Kernel density contour (at 95, 70, 50, $25 \%$ probability to find the fish). 


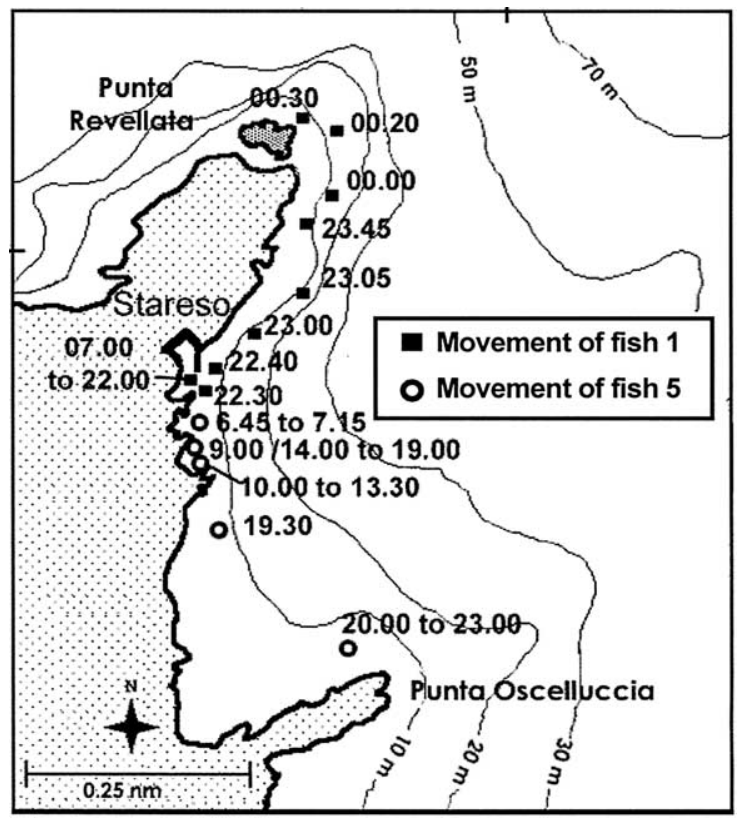

Fig. 4. Recorded positions of two Sarpa salpa tracked in the Bay of Calvi. Squares indicate fish 1 positions during the 10th of June 2000. Circles indicate fish 5 positions during the 18th of June 2000. Time of the location is indicated next to it.

until 23:00 (end of the tracking period for this day) (0.7 BLF per second) (Fig. 4).

The tracked fish were essentially located over $0-5 \mathrm{~m}$ bottom depth during the four periods of the 24-h cycle (Table 4). Contingency tables indicated that the utilisation of the four bottom depth classes during the day and the night periods and the day and the dusk periods were heterogeneous (respectively $\chi^{2}=8.569 ; P<0.05$ and $\chi^{2}=9.885$; $P<0.05$ ). Moreover, our observations indicated that the tracked fish usually moved over deeper areas during dusk and early night.

\section{Discussion}

This first tracking study on $S$. salpa enabled us to determine the diel activity pattern of this species in the Mediterranean from June to September. For accuracy, the number of locations and the approach at the individual scale, this study was innovative and allowed a better assessment of the behavioural ecology of a seldom-studied species.

\section{Table 4}

Percentage of positional fixes over the bottom depth for the four different periods of the day (averaged over all data)

\begin{tabular}{lcccc}
\hline Depth & Dawn & Day & Dusk & Early night \\
\hline $0-5 \mathrm{~m}$ & 74 & 84 & 66 & 68 \\
$5-10 \mathrm{~m}$ & 19 & 13 & 24 & 20 \\
$10-20 \mathrm{~m}$ & 4 & 2 & 9 & 8 \\
$>20 \mathrm{~m}$ & 3 & 1 & 1 & 4 \\
\hline
\end{tabular}

It is currently admitted that intraperitoneal implantation of a transmitter is presumably an adequate tagging procedure for studying fish behaviour (Eristhee and Oxenford, 2001; Lowry and Suthers, 1998; Klimley et al., 2001; Paukert et al., 2001). Moreover, in our study, SCUBA diving observations suggest that the behaviour described does not originate from tagging artefacts and that a few hours after release, tagged fish reintegrated a school and rapidly adopted similar behaviour to the rest of the group.

Our observations suggest that in the June-September period, S. salpa specimens regularly move within their home range, which extends from 0.85 to 5 ha. The tracked individuals were located in different parts of Calvi Bay and over different depth levels $(0-30 \mathrm{~m})$, but chiefly at shallow depths. Most individuals alternatively used well-defined sites, suggesting their ability to recognise different parts of their home range. The stimuli used to determine direction may include vision through the recognition of landmarks, olfactory stimulation, the use of a sun compass, and the direction of currents (Hasler and Wisby, 1958). These regular diel migrations within the home range, which may include different habitats, have already been recognised for different marine species in order to optimise the use of space (i.e. migrations between feeding and sheltered areas) (Holland et al, 1993, 1996; Bruke, 1995). This tracking study has clearly demonstrated the existence of inter-individual differences concerning the extension of the home range and patterns of movement. As the fish were tracked separately, it is difficult to determine the source of the inter-individual differences in their mobility pattern. These could originate from the size or the nature of the shoal reintegrated by the tagged fish, the time-interval from spawning period (unknown in Mediterranean), the periods of the year (June-September) or from different environmental conditions. Two major kinds of behavioural patterns have been observed. Firstly during the day, the fish remained in the close vicinity of the harbour, but moved away at dusk to the north or south. The second behaviour consisted in an unchanged occupation of the same sites during day and night in a restricted home range. All the fish but two alternatively adopted the two different types of behaviour. This observation explains the importance of variations in our results (high SD).

The tagged $S$. salpa showed contrasting patterns of activity during the four periods of the 24-h cycle, and were less mobile during the day. All the tracked fish but one showed an important peak of mobility during dusk and the early night, and to a lesser degree during dawn. The existence of a specific activity pattern in $S$. salpa is not surprising. This distinct activity pattern, with a peak of activity at twilight, has been observed previously in several species (red morrow, Cheilodactylus fuscus, Lowry and Suthers, 1998; the seabass, Dicentrarchus labrax, Bégout and Lagardère, 1995; Bégout-Anras et al., 1997; BégoutAnras and Lagardère 1998; the brown trout Salmo trutta, Ovidio et al., 1998, 2002). Nocturnal and crepuscular 
activity was usually suggested to be a response to reduced predation risk (Heggens et al., 1993; Jonsson and Jonsson, 1993), an adaptation to prey availability, or optimal foraging strategy in relation to the water temperature (Baras, 1995). For S. salpa, it would be necessary to track more individuals in different seasons to interpret this particular behaviour pattern.

The utilisation of the water column varied over different periods of the 24-h cycle. Sarpa salpa stays in shallow water $(<10 \mathrm{~m})$ and the only intrusion to deeper areas occurred exclusively during the crepuscular period. Interestingly, Gobert et al. (2002) indicate that between June and August, in our study site of the Calvi Bay, the coefficient A (i.e. \% of leaves without apex, Giraud, 1979) of the seagrass $P$. oceanica is the highest $(0-78 \%)$ in shallow bathymetric waters $(0-12 \mathrm{~m})$, and the lowest $(0-21 \%)$ in deeper waters (20-38 m). The percentage of broken apices can be related either to grazing or to water movements, usually more important in shallow waters (in Gobert et al., 2002). As $S$. salpa are essentially located in shallow waters and graze in this area mainly the P. oceanica (Antolic et al., 1994; Havelange et al., 1997; Jadot et al., 2000a, b; Velimirov, 1984; Verlaque, 1990), this suggests that $S$. salpa mainly graze when they are in shallow waters and decrease their foraging activity when they move away to deeper areas. Results also indicate that it would be necessary to make a distinction between mobility and activity, as $S$. salpa can forage actively with restricted mobility.

This study has provided evidence that acoustic tracking is an effective way of monitoring movements of individual $S$. salpa. Nevertheless, further studies have to be done to obtain a complete knowledge on patterns of movement during the night and at different seasons. Determining the different types of habitats used by the fish within the home range is also required. This will lead to a better understanding of the tactical and strategic meaning of those movements.

\section{Acknowledgements}

Support for this paper was provided by a $\mathrm{PhD}$ research grant from FRIA (Fonds pour la Formation à la recherche dans l'Industrie et l'Agriculture) to the first author. The authors wish to tanks Holly Cleator from the Freshwater Institute (Department of Fisheries and Oceans; Winnipeg, Canada) for the loan of the VR60 receiver and the hydrophone. Authors wish to thank Dr. M.L. Bégout-Anras for constructive comments on the early draft of the manuscript and the anonymous referee for their relevant revision.

\section{References}

Alcoverro, T., Duarte, C.M., Romero, J., 1997. The influence of herbivores on Posidonia oceanica epiphytes. Aquat. Bot. 56, 93-104.
Antolic, B., Skaramuca, B., Span, A., Musin, D., Sanko-Njire, J., 1994. Food and feeding habits of a herbivore fish Sarpa salpa (L.) in the southern Adriatic (Croatia). Acta Adriat. 35, 45-52.

Baras, E., 1995. Thermal related variations of seasonal and daily spawning periodicity in Barbus barbus. J. Fish. Biol. 46, 915-917.

Bay, D., 1984. A field study of the growth dynamics and the productivity of Posidonia oceanica (L.) in Calvi Bay, Corsica. Aquat. Bot. 20, 43-64.

Bégout, M.L., Lagardère, J.P., 1995. An acoustic telemetry study of sea bream (Sparus aurata): first results on activity rhythm, effect of environmental variables and space utilisation. Hydobiologia, 417-423.

Bégout-Anras, M.L., Lagardère, J.P., Lafaye, J.Y., 1997. Diel activity pattern rhythm of seabass tracked in a natural environment: group effects on swimming pattern and amplitudes. Can. J. Fish. Aquat. Sci. $54,162-168$.

Bégout-Anras, M.L., Lagardère, J.P., 1998. Variabilité météorologique et hydrologique. Conséquences sur l'activité natatoire d'un poisson marin. C. R. Acad. Sci. Paris 321 (Série III), 641-648.

Bruke, N.C., 1995. Noctural foraging habits of French and blue stripped grunts, Haemulon flavolineatum and H. scirus, at Tobacco Caye, Belize. Environ. Biol. Fish 42, 265-374.

Cebrian, J., Duarte, C.M., Marba, N., Enriquez, S., Gallegos, M., Olesen, B., 1996. Herbivory on Posidonia oceanica: magnitude and variability in the Spanish Mediterranean. Mar. Ecol. Prog. Ser 130, $147-155$.

Dance, C., 1987. Patterns of activity of the sea urchin Paracentrotus lividus in the Bay of Port-Cros (Var, France, Mediterranean). Mar. Ecol 8, 131-142.

Eristhee, N., Oxenford, H.A., 2001. Home range and use of space by Bermuda chub Kyphosus sectatrix (L.) in two marine reserves in the Soufrière Marine Management Area, St Lucia, West Indies. J. Fish. Biol. 59, 129-151.

Francour, P., 1997. Fish assemblages of Posidonia oceanica beds at Port Cros (France, NW Mediterranean): Assessment of composition and long-term fluctuactions by visual census. Mar. Ecol 18, 157-173.

Francour, P., 2000. Evolution spatio-temporelle à long terme des peuplements de poissons des herbiers à Posidonia oceanica de la réserve naturelle de Scandola (Corse, Méditerranée nord-occidentale). Cybium 24, 85-95.

Giraud, G., 1979. Sur une méthode de mesure et de comptage des structures foliaires des Posidonia oceanica Delile. Bull. Mus. Nat. Marseille 39, 33-39.

Gobert, S., Kyramarios, M., Lepoint, G., Pergent-Martini, C., Bouquegneau, J.M., in press. Microstructure de l'herbier à Posidonia oceanica (L.) Delile et relation avec les paramètres physico-chimiques du sédiment. Oceanol. Acta. in press.

Harmelin-Vivien, M.L., 1983. Etude comparée de l'ichtyophone des herbiers de phanérogames marines en milieu tropical et tempéré. Rev. Ecol. (Terre et Vie) 38, 179-210.

Harmelin-Vivien, M.L., Francour, P., 1997. Trawling or visual census? Methodological bias in the assessment of fish population in seagrass beds. Mar. Ecol. 13, 41-51.

Hasler, A.D., Wisby, W.J., 1958. The return of displaced large mouth bass and green sunfish to a "home area". Ecology 39, 289-293.

Havelange, S., Lepoint, G., Dauby, P., Bouquegneau, J.M., 1997. Feeding of the sparid fish Sarpa salpa in a seagrass ecosystem: diet and carbon flux. Mar. Ecol. 18, 287-297.

Heggens, J., Krog, O.M.W., Lindas, O.R., Dokk, J.G., Bremnes, T., 1993. Homeostatic behavioural responses in a changing environment: brown trout (Salmo trutta) become noctural during winter. J. Anim. Ecol. 62, 295-308.

Holland, K.N., Lowe, C.G., Peterson, J.D., Gill, A., 1992. Tracking coastal sharks with small boats: Hammerhead shark pups as a case of study. Aust. J. Mar. Freshwater Res. 43, 61-66.

Holland, K.N., Peterson, J.D., Lowe, C.G., Wetherbee, B.M., 1993. Movements, distribution and the growth rates of the white goatfish 
Mulloides flavolineatus in a fisheries conservation zone. Bull. Mar. Sci. 52, 982-992.

Holland, K.N., Lowe, C.G., Wetherbee, B.M., 1996. Movement and dispersal patterns of blue trevally (Carnax melampygus) in a fisheries conservation zone. Fish. Res. 25, 279-292.

Hooge, P.N., Eichenlaub, B., 1997. Animal movement extension to arcview. Version 1.1. Alaska Biological Science U. S. Center Geological Survey, Anchorage, AK, USA.

Jadot, C., Graux, D., Michel, C., Voss, J., 2000a. Contribution à la caractérisation du comportement reproducteur et alimentaire de la Saupe (Sarpa salpa (Linné, 1758). Cah. Ethol. Appl. 20, 33-44.

Jadot, C., Houziaux, J.S., Voss, J., 2000b. Determination of the enzyme potentiality of the digestive tract of Sarpa salpa in order to study its diet in the Mediterranean Sea (Corsica, France). Comp. Biochem. Physiol. 126, 73.

Jonsson, B., Jonsson, N., 1993. Partial niche shift versus sexual maturation in fishes. Rev. Fish. Biol. Fish. 3, 348-365.

Klimley, A.P., Le Boeuf, B.J., Cantara, K.M., Richert, J.E., Davis, S.F., Van Sommeran, S., 2001. Radio-acoustic positioning as a tool for studying site-specific behavior of the white shark and other large marine species. Mar. Biol. 138, 429-446.

Lepoint, G., Nyssen, F., Gobert, S., Dauby, P., Bouquegneau, J.M., 2000. Relative impact of seagrass bed and its adjacent epilithic algal community in consumer diets. Mar. Biol. 136, 513-518.

Lorwry, M.B., Suthers, I.M., 1998. Home range, activity and distribution patterns of a temperate rocky-reef fish, Cheilodactylus fuscus. Mar. Biol. 132, 569-578.

Mazzella, L., Buia, M.C., Gambi, M.C., Lorenti, M., Russo, G. F., Scipione, M.B., Zupo, V., 1992. Plant and animal interaction in the marine benthos. In: John, D.M., Hawkins, S.J., Price, J.H. (Eds.), Systematics Association, Special vol. 46. Clarendon Press, Oxford, pp. 165-187.

Mendez-Villamil, M., Pajuelo, J.G., Lorenzo, J.M., Coca, J., Ramos, A.G., 2001. Age and growth of the salema, Sarpa salpa (Osteichtyes, Sparidae), off the Canary Islands (East-Central Atlantic). Arch. Fish. Mar. Res. 49, 139-148.
Ott, J., Maurer, L., 1977. Strategies of energy transfer from marine macrophytes to consumer levels: the Posidonia oceanica example. Pergamon Press, Oxford pp. 493-502.

Ovidio, M., Baras, E., Goffaux, D., Birtles, C., Phillipart, J.C., 1998. Environmental unpredictability rules the autumn migrations of trout (Salmo trutta) in the Belgian Ardennes. Hydrobiologia 371/372, 262-273.

Ovidio, M., Baras, E., Giroux, F., Goffaux, D., Phillipart, J.C., 2002. Seasonal variation of activity pattern of brown trout (Salmo trutta) in a small stream, as determined by radio-tracking. Hydrobiologia 470, 195-202.

Paukert, C.P., Chavala, P., Heikes, B.H., Brown, M.L., 2001. Effect of implanted transmitter size and surgery on survival, growth, and wound healing of bluegill. Trans. Am. Fish. Soc. 130, 975-980.

Pergent, G., Romero, J., Pergent-Martini, C., Mateo, M.A., Boudouresque, C.F., 1994. Primary production, stocks and fluxes in the Mediterranean seagrass Posidonia oceanica. Mar. Ecol. Prog. Ser. 106, 139-146.

Peirano, A., Niccolai, I., Mauro, R., Bianchi, C.N., 2001. Seasonal grazing and food preference of herbivores in a Posidonia ocanica meadow. Sci. Mar. 65, 367-374.

Ros, J.D., Romero, J., Ballesteros, E., Gili, J.M., 1984. Diving in the blue water. The benthos. In: Margalef, R. (Ed.), Western Mediterranean. Pergamon, Oxford, pp. 233-295.

Ruitton, S., Francour, P., Boudouresque, C.F., 2000. Relationships between algae, benthic herbivorous invertebrates and fishes in rocky sublittoral communities of a temperate sea (Mediterranean). Estuar. Coast. Shelf Sci. 50, 217-230.

Velimirov, B., 1984. Grazing of Sarpa salpa (L.) on Posidonia oceanica and utilization of soluble compounds. In: Boudouresque, C.F., Jeudy de Grissac, A., Olivier, J. (Eds.), International Workshop on Posidonia oceanica Beds. GIS Posidonie Publication, Marseille 1, pp. 381-387.

Verlaque, M., 1990. Relation entre Sarpa salpa (Linnaeus, 1758) (Téléostéen, Sparidae), les autres poissons brouteurs et le phytobenthos algal Méditerranéen. Oceanol. Acta 13, 373-388. 